reproductive performance was compared with the mean of the two pure strains (o p. Ioo heterozygosity). The litters carried by all the females were sired by a third genetically distinct strain, in order to standardise foetal heterosis and thus any differences between the females of different p. Ioo heterozygosity would be exclusively maternal heterosis. A highly significant positive linear relationship was found between heterosis and heterozygosity in litter size and total weight of litter (at birth and at weaning) and in adult female weight. Individual weight of progeny at birth showed no heterosis, and the relationship between heterosis and heterozygosity in individual weight of progeny at weaning was only slightly positive. However the fact that no decrease was found in individual weight of progeny within litter (at birth and at weaning) may in fact be evidence of heterosis since one would expect a decrease in individual weight as litter size increased. The relevance of these results to pig breeding is discussed.

\title{
DIE ROLLE DER INZUCHT IN DER SCHWEINEZÜCHTUNG
}

\section{G. TIREBLER. - Humboldt-Universität Berlin, DDR, Beveich Tiersüchtung und Haustiergenetik.}

Systematische Inzuchtanwendung hat bei der Züchtung von Schweinerassen nur in Ausnahmefällen einc Rolle gespielt. Umfangreiche Inzuchtexperimente beweisen dass hohe Inzuchtraten/ Generation die Entwicklungshomeostase und die genetische Homeostase so stark mindern, dass nach wenigen Generationen die meisten Linien nicht mehr lebensfähig sind. Auch bei Anwendung niedriger Inzuchtraten werden die Merkmale der Reproduktionsleistung negativ beeinflusst. Mit zunehmonder Heritabilität (Heritabilität im engeren Sinne) der Merkmale nimmt die negative Beeinflussung durch Inzucht ab. Unter Berücksichtigung der Vermehrungsrate, der relativ hohen Inzuchtdepressionen bei den ökonomisch whichtigen Merkmalen der Fruchtbarkeit und Jugendentwicklung sowie der zu erwartenden Heterosiseffekte haben Inzuchtlinien in der Schweinezüchtung wenig Erfolgschancen.

Bei Reinzuchtprogrammen wird die realisierbare Selektionsintensität von den negativen Inzuchtwirkungen bestimmt. In Hybridzuchtprogrammen sollten Mutterlinien über Verwandtschaftszucht genetisch vereinheitlich werden, wobei aber höhere Inzucht wegen ihren Depressionen und Aufspaltungswirkungen in viele Unterpopulationen zu vermeiden ist. Das kann durch Notation von abergrappen erreicht werden.

In Eberlinien ist ein begrenzter Eineatz von 4-6 Eber/Generation ausschliesslich nach ihrem Zuchtwert angebracht. Gezielte Inzuchtpaarungen sind in eberlinien erstrebenswert, wene zuvor auf Grund von Testpaarungen besondere Kreuzungseffekte über Topcross emmittelt worden sind.

\section{FSTIMATION OF CROSSBREEDING PARAMETERS IN PIGS}

\author{
D. Fewson and W. Schlote. - Department of animal A usbandry and animal Breeding, Hohenheim \\ university.
}

A crossbreeding experiment in pigs with 25 genetical groups was used to estimate some crossbreeding parameters. The model for the means of the crossbreeding groups included the direct effect of the piglets, the maternal and paternal effects as well as the corresponding heterotic effects and recombination losses. Due to the experimental design some of the effects were confounded: A regression analysis was used to estimate the crossbreeding parameters. The results for three preweaning traits, litter size at birth and at weaning and individual weight at weaning. are presented.

The estimated crossbreeding parameters corresponded in general to their expectations. Only a few of them were unrealistic high. But the standard errors of the estimates were all quite high. With the data of this experiment the crossbreeding parameters could not be estimated very accurately.

For the three preweaning traits go p. Ioo or more of the variance of the group means were determined by the regression. The variation of the group means about the regression line was not significantly greater than the variance within the groups. Therefore the underlying model must have included the most substantial constituents of the group means. Special analyses without the paternal effects lead only to a small reduction of the correlation coefficients. In this material the influence of the paternal effects was not important at all. 